\title{
GENDERING DANCE, GAZING MUSIC: DANCE MOVEMENTS, HEALING RITUALS AND MUSIC MAKING OF SAMA BAJAU AND SAMA DILAUT OF EAST MALAYSIA AND SOUTHERN PHILIPPINES
}

\author{
Mohd Anis Md Nor ${ }^{1 *} \&$ Hanafi Hussin ${ }^{2 * *}$ \\ *first author, **corresponding author \\ ${ }^{1}$ Nusantara Performing Arts Research Centre (NusPARC), Malaysia \\ ${ }^{2}$ Department of Southeast Asian Studies, Faculty of Arts and Social Sciences \\ ${ }^{2}$ Institute of Ocean and Earth Sciences (IOES) \& \\ ${ }^{2}$ Social Advancement and Happiness Research Cluster \\ University of Malaya, Malaysia \\ (anisnor55@um.edu.my, hanafih@um.edu.my) \\ DOI: https://doi.org/10.22452/samudera.vol1no1.6
}

\begin{abstract}
Amongst the Sama and Bajau of the Sulu Sea (formerly referred to as 'sea gypsies'), the Sama Bajau of Malaysia (who no longer roam the sea but live in coastal hamlets and villages) and the Sama DiLaut of the Southern Philippines share commonalities in the way dancers are gendered through the choices of musical tunes while partaking in the ritual healing ceremony of Magpaibahau or Magduwata (amongst Sama Bajau and Bajau Laut in Malaysia), Mag-paigal (Bajau Laut in Semporna, Malaysia and in Sitangkai, Philippines), or Pagkanduli (Sama Dilaut in Sitangkai, Philippines). The tagunggu' ensemble with the kulintangan pot gong set, agung (two big hanging gongs) or tawag (large gong), and tambul (drum) play tunes or titik for the spirit bearer (Jin), which is represented by Jin Lella (male Jin) or Jin Denda (female Jin). The tunes (titik) may also signify the places where these events take place such as Titik Lellang for the Magduwata ritual amongst Sama Bajau in Semporna, East Malaysia or Titik Limbayan for the Pagkanduli ritual of the Sama Dilaut in Sitangkai, Southern Philippines. Similarly, these tunes are associated with the gender of the spirit-bearers, Titik Lellang for the male spirit bearer and Titik Limbayan for female spirit-bearers. Dances or igal of the spirit-bearers in these communities are also identified and named after the tunes, such as Igal Lellang and Igal Limbayan respectively. This paper aims to highlight the responses between the tagunggu'/kulintangan musicians and the dancing spirit-bearers in these two locations: Semporna in East Malaysia and Sitangkai in the Sulu Archipelago in Southern Philippines as they reciprocate on the gazes of the dancing spirit-bearers in sustaining appropriate rhythmic pulses to the tunes of gendered musical styles.
\end{abstract}

Keywords: Magpaibahau, Magduwata, Magpaigal, Pagkanduli, Jin Lella, Jin Denda, Sama Dilaut, Sama Bajau, Semporna, Sitangkai 


\section{Prologue}

Within the community of the nomadic 'sea gypsies' of the Sulu Sea, the Sama Bajau or Bajau Laut of Malaysia and the Sama Dilaut of the Southern Philippines share commonalities in the way dancers are gendered through the choices of musical tunes while partaking in the ritual healing ceremony of magpaibahau or magduwata (offering of newly harvested rice) and magpa-igal (for ancestors' spirit) or in the offering ceremony of pagkanduli (offerings for sea-spirits). Ritual healing ceremonies are signified with dancing (mag-igal) and playing of specific tunes (titik) by the kulintang music, which is often referred to as tagunggu', consisting of a set of graduated pot gongs, agung (two big hanging gongs) or tawag (large hanging gong), and tambul (double-headed snare drum). The tunes (titik) played for ritual healing ceremonies are meant for the spirit bearer (jin), which is represented by male spirit bearer (jin lella) or female spirit bearer (jin denda). The tunes (titik) may also signify the places where these events take place such as titik lellang for the magduwata ritual amongst Bajau Kubang in Semporna, East Malaysia or titik limbayan for the pagkanduli ritual of the Sama Dilaut in Sitangkai, in the Southern Philippines. Similarly, these tunes are associated with the gender of the spirit-bearers, such as titik lellang for the male spirit bearer (jin lella) and titik limbayan for female spirit-bearer (jin denda). In other words, musical tunes of the tagunggu' or kulintang ensemble played during the ritual healing ceremonies are identified with the gender of the spirit (Jin), which have entered into the spirit bearers bodies, hence a male spirit bearing body may either become a male spirit (jin lella) or a female spirit (jin denda). As an extension to the markers of gendering bodies, dance or igal within the context of these rituals are also identified and named after the tunes, such as igal lellang and igal limbayan respectively. This paper aims to highlight the responses between the tagunggu'/kulintang musicians and the dancing spirit-bearers in these two locations: Semporna in East Malaysia and Sitangkai in the Sulu Archipelago in Southern Philippines as they reciprocate on the gazes of the dancing spirit-bearers in sustaining appropriate rhythmic pulses to the tunes of gendered musical styles.

\section{Sea Gipsies of Malaysia and the Philippines - Sama Bajau (Bajau Kubang) Malaysia and Sama Dilaut (Bajau Laut) the Philippines}

Linguistically and culturally diverse, the Bajau or Sama are distributed throughout the region from the Southern Philippines, along with coastal areas of Sabah and parts of eastern Indonesia. Sabah has two major Bajau culture complexes - the west coast Bajau, and the east coast Bajau. Although all these were traditionally dependent on the sea, they differ widely in terms of languages, culture and history. The west coast Bajau, especially in the Kota Belud area, have been heavily influenced by the Iranun, a smaller but historically dominant maritime people. Those along the east coast show strong Suluk (Tausug) influence in their cultures (Pugh-Kitingan, Hussin \& Baptist, 2005).

The Bajau Kubang who are also known as Bajau Sikubang, are said to be the largest Sama group in the Semporna area of southeast Sabah. The term kubang means "gathering" or "settling in groups." According to their genealogies, the Bajau Kubang 
were the original inhabitants of the area, traditionally settling on Omadal Island, then spreading to Larapan and Bumbum Islands, and finally coming to the mainland several generations ago. They speak a dialect, often called Bajau Semporna, of the Southern Samal dialect chain (Sather, 2004; Walton \& Moody, 1984). A settled shore people, they are renowned throughout the region as expert wood craftsmen, boat-builders, ironsmiths, mat-makers, and producers of tortoiseshell combs and pendants. Sather notes that in 1965, the most beautiful lepa boats in the region were produced by the Bajau Kubang of Kampung Kambimbangan (Kabimbangan), Nusalalung and other villages of Bumbum Island (Sather, 2000). Other traditional socioeconomic activities include fishing and related work, supplemented with land-based practices such as hunting and the cultivation of coconut trees, cassava and, in the past, hill rice. Nowadays, many have abandoned traditional fishing activities and work as civil servants and businesspeople (Pugh-Kitingan, 2005).

The Bajau Kubang is an egalitarian society with a bilateral descent system. They live in villages composed of hamlets of single dwellings, dispersed along the shorelines. Each house contains several rooms, with a full spacious mooring jetty in front and a kitchen at the back. The nuclear family is the fundamental social unit, but households frequently include other kin such as grandparents. Elderly folk are respected in the family and the broader community for their wisdom, knowledge and sometimes for spiritual power. Marriage is generally exogamous to second parallel cousin level, but first cousin marriages are permitted between the children of sisters (due to matrilateral bias) and is often endogamous within the village (Pugh-Kitingan, 2005).

The Sama DiLaut is more diasporic in their demographic distribution over the coral reefs of Tawi-Tawi, the seas around Sibutu Islands and the tidal flats of Jolo and Basilan, but in many ways are similar to the egalitarian and bilateral descent social structure of the Bajau Kubang. The Sama DiLaut live as a nuclear family within a conjugal boat crew comprising of husband, wife and dependent children, living exclusively on fishing and gathering of sea products such as tripang or sea-cucumber, pearl-bearing oysters and decorative shells. Conjugal families that are linked by kinship ties and mutual economic interest form a multi-family household (luma') in on-shore pile house dwelling, which may become part of household clusters that form a village. However, the mobility of the conjugal family boat crew is often dictated by wind and tidal patterns taking them to various fishing sites around the coral reefs (King, 1993; Sather, 1997).

\section{The Rituals: Magpaibahau and Magduwata, Pagkanduli \& Magpa-igal}

\section{Magpaibahau-Magduwata}

Bajau Kubang, Bajau Laut or Sama DiLaut communities practice annual rice offering or Magpai-bahau through séance dancing and music-making in the Magduwata rituals. Both of these are mandatorily performed annually to signify thanksgiving reunion of family members for a bountiful year and assurance of ancestral blessings for good health and plenteousness future. Sather remarked how this event, which he referred to as Magpai Baha'u, was celebrated by the Bajau Laut (Sea Gypsies) in the village of Kampung Bangau-Bangau in Semporna. 
Magpai baha' $u$, marking the return of the ancestors, opens with the fashioning of the kulit mbo'. At midday, the bin is filled with new rice. Next comes the nightly dancing of the jin, followed in the morning by the preparation of the new rice (Sather, 1997), climaxing with the midday feasting of the ancestors (Sather, 1997). Finally, the rite concludes with early morning bathing (Sather, 1997). In addition to magpai baha'u, the mediums perform further public dances during the year, called mag-igal jin, meant to entertain the village ancestors and the numerous spirits believed to inhabit the surrounding region, and so preserve their continued goodwill. Such dancing is also thought to have a therapeutic virtue, as the spirit guests are said to bear off with them when they disperse the various afflictions and woes suffered by village members. Tandoh ([sic] an informant) insists that there is a marked improvement in village health following mag-igal jin. Garani ([sic] another informant) maintains that, by tradition, such dancing should be performed every lunar month, on the fourteenth or fifteenth night, during the full phase of the moon. This is also the time in which magpai baha' $u$ is performed (Sather, 1997). In practice, the dancing is held less regularly, or at least it was in 1964-5. Its time and planning are fixed by a meeting of mediums called by the nakura' jin (Sather, 1997).

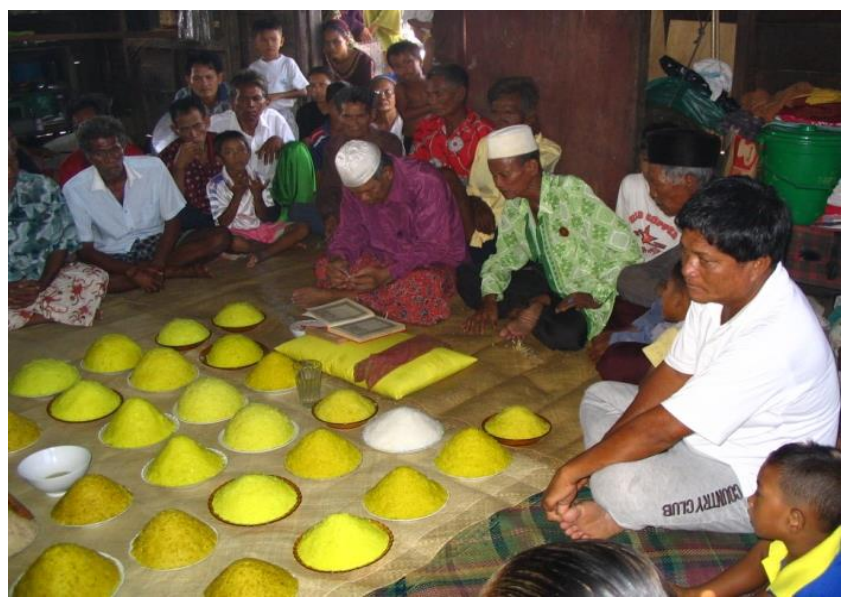

Figure 1: Magpai-bahau of Bajau Laut Kampung Bangau-Bangau, Semporna, Sabah (Source: Fieldwork, 2005)

The magpabahau ritual of the Bajau Kubang in Bumbum Island, replicates the same rituals observed by the Bajau Laut (Sea Gypsies) in Bangau-Bangau Village as described by Sather. The primary offering of newly harvested hill rice is accorded with a privileged status in the Kok dulang or offering tray. Aside from newly harvested de-husked hill rice, other offerings include coconuts, sugar canes and corns. All these are processed, cooked and offered within the three days to the ancestors. This event is commonly known as magjamu ni ka omboan or magpataluwak ni ka omboan (to feed offerings to the ancestral spirits). 


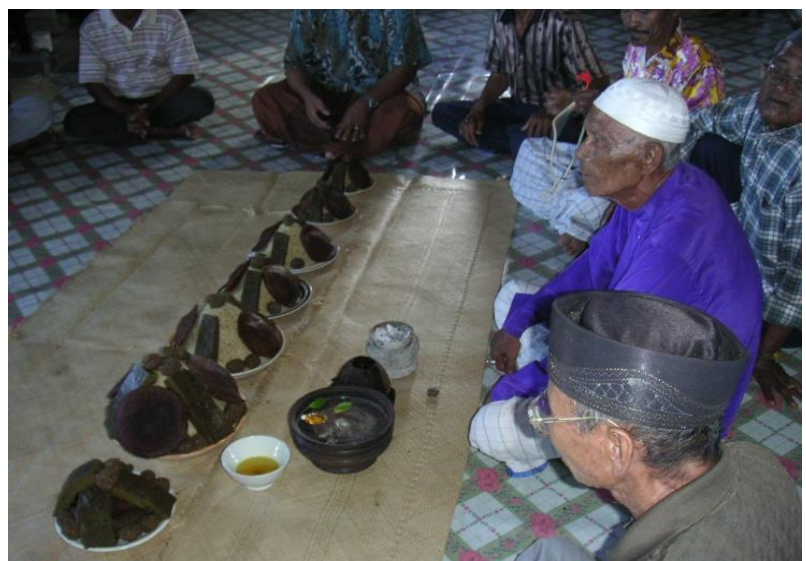

Figure 2: Magpaibahau-Magduwata of Bajau Kubang of Semporna, Sabah

(Source: Fieldwork, 2005)

The ritual of magpaibahau takes place through the séance of magduwata, which engages the crossing of worlds between the living and the spirit guides, known as jin amongst the Bajau Kubang or bansa amongst the Sama Dilaut or Bajau Laut. The term jin refers to both the spirit guide as well as the spirit bearer (shaman or medium). Distinction is made between the spirit bearer, jin for male spirit bearer or limbagan for female spirit bearer, and the spirit-guide that may manifest in the form of male spirit guide (jin lela) or female spirit guide (jin denda) irrespective of the gender of the shamanic spirit bearer through ritual séance of magduwata. In other words the spirit bearer is the crucible for spiritual access into the world of the spirit guide.

Offerings of newly harvested hill rice with other sweet meals not only acknowledges the continuity of ancestral lineage (katurunan) but also as a means of preventing curses (kabusongan or katulahan), which are related to displeased spirit guides for the failure of looking after ancestral heirloom known as langkapan. The langkapan is the collective nexus and conduits of spiritual energies between the ancestral spirits and the world of the living. Other than the required compliance to offer newly harvested hill rice or fulfilling the indigenous filial calendars, kabusongan may also happen due to the lack of respect to langkapan, which had been passed down from one generation to the other. These tangible cultural objects must be ritually blessed according to the indigenous ancestral calendar of magruwata kok taon, which is usually observed during the Islamic month of Rejab, two months before the advent of the holy Islamic fasting month of Ramadhan (Md Nor \& Hussin, 2006).

The crossing over of spirit guide (jin lela or jin denda) into the abode of the spirit bearer (jin or limbagan) climaxes during the final rites of the magduwata ritual which engages the crossing of worlds between the living and the spirits. This climatic event is marked by magtagunggu' (playing of the tagunggu'/kulintang ensemble) and 
involves spontaneous or trance-induced dancing (mag-igal). The tagunggu' ensemble is made up of a set of small kettle or pot gongs placed on a wooden rack, a double-headed snare drum called tambul or tambol, two large hanging gongs called agung and/or a single large hanging gong, tawag. This tagunggu'/kulintang ensemble is conventionally handed down from one generation to the other and is considered to be integral to the langkapan tangible objects or ancestral heirloom. The tagunggu' must be well looked after, like the rest of the langkapan, and played by an expert. Any violation against taboos in the playing and caring of the tagunggu' ensemble may also bring ancestral curse leading to kabusongan or katulahan.

\section{Magpa-igal}

Séancing magduwata is achieved through a complex intermixing of music making (magtagunggu') and dancing (magpa-igal). Spirit bearers perform the magpa-igal jin/magpa-igal limbagan by being induced both by the musical tunes of the tagunggu'/kulintang ensemble and kata-kata (esoteric incantations), which are in a mixed Islamic and indigenous texts. Dancing the igal (dance) between male and female dancing shamans are very much similar to the styles of male and female igal-dancing or mag-igal common throughout the Bajau Laut and Sama Dilaut communities in Sabah and Tawi-Tawi, Sibutu and Jolo islands.

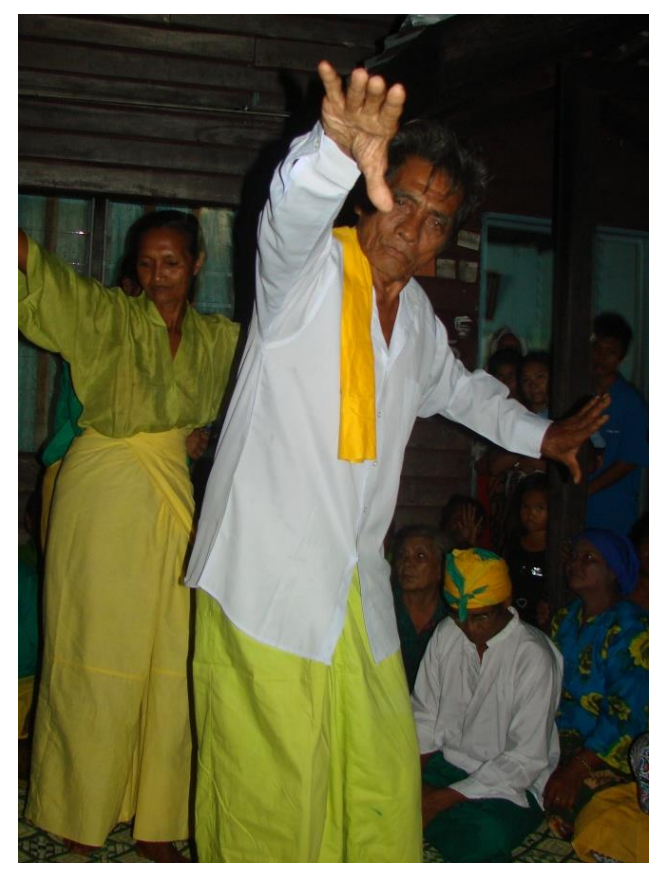

Figure 3: Magpaigal Jin of Bajau Laut of Bangau-Bangau, Semporna, Sabah (Photo: courtesy of Judeth John Baptist, Sabah Museum) 
However, spirit bearers as shamanic practitioners are intrinsically bounded by bodily gestures, subtle or blatantly expressed through dancer's carriage, arms and hands movements, which signify gender of the spirit guide that have entered (masuk) the body of the spirit bearer known to the members of shamanic fraternity who are descendants of male spirit bearers or female spirit bearers (jin or limbagan). They are empowered to communicate with the spiritual world either with those of their ancestors or even with malicious spirits or syaitan. The spirit bearers congregate and perform the magpa'igal jin (dancing spirit bearer) ritual together over an average of a three-month cycle to rejuvenate their shamanic abilities as well as to serve as a form of celebration to pay homage to their ancestral spirits (Baptist \& Regis, 2010). Without that, curses in the form of unexplained sickness or bad luck (busog or katulahan) may befall onto themselves or members of their families.

Performing this ceremony is essential to the well-being of the spirit bearer (jin) and ordinary members of their community. Neglecting these obligations may result in recurrent illness or personal calamities inflicting those who possess powers of the jin. It is important to note that in the case of the Bajau Laut, the magpa'igal jin would conventionally begin in the Southern Philippines island of Sitangkai before continuing its journey to the Bajau Laut's village of Kampung Bangau-Bangau in Semporna, Sabah. Hence, dancing styles of the igal by Bajau Laut or Sama Dilaut have become amorphous and less distinctive between the two. The same could be said in the music repertoire of the tagunggu'/kulintang ensemble. Little has changed from the field recordings done by Jose Marceda in 1982, which are cited below.

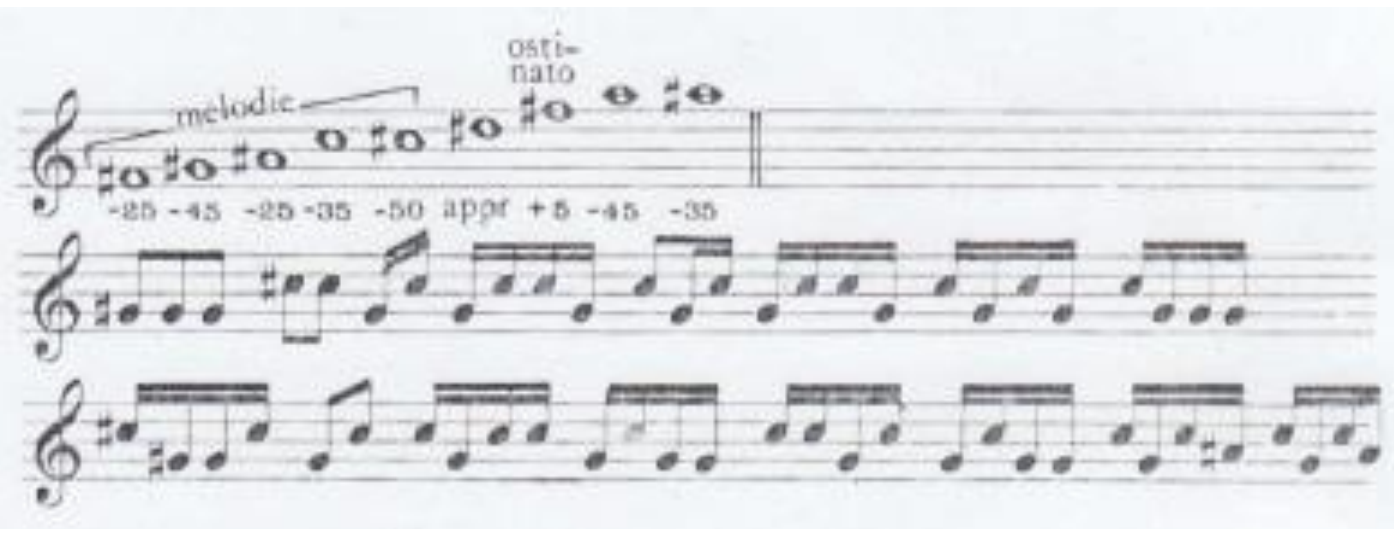

Figure 4: Titik Limbayan

Source: "Sama de Sitangkai," a record of music and excerpts of kata-kata by Alain Martenot and Jose Maceda, ORSTOM - 1982 (page 6) 


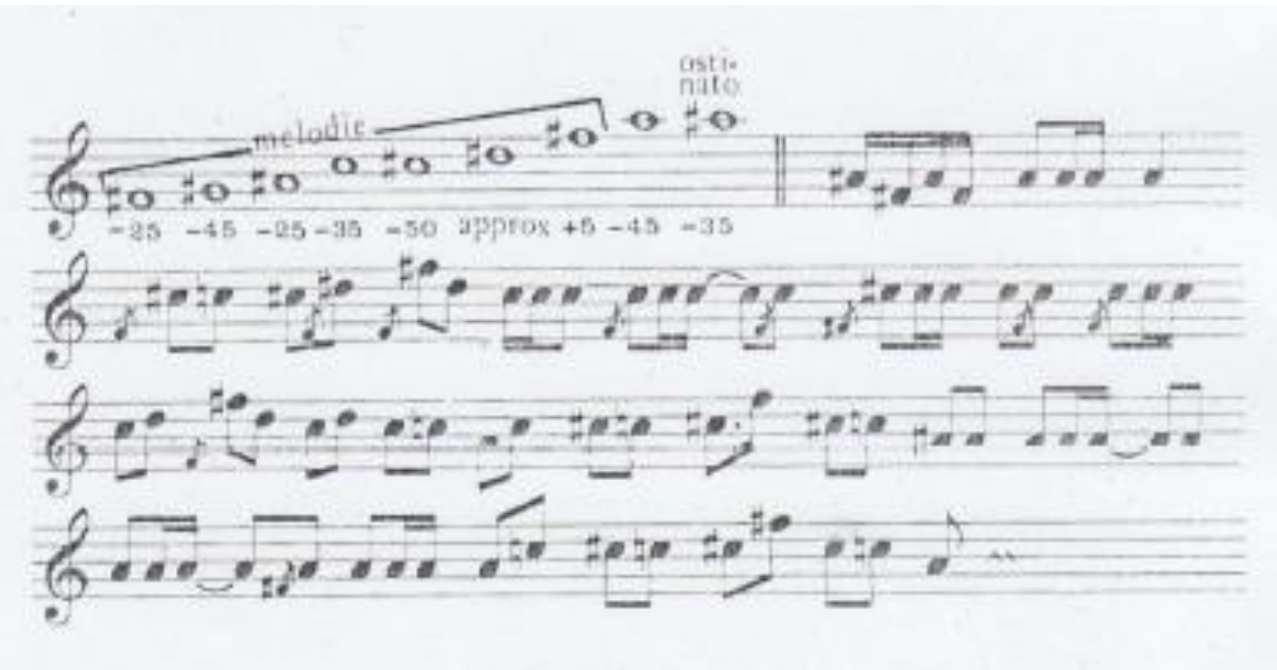

Figure 5: Titik Jin

Source: "Sama de Sitangkai," a record of music and excerpts of kata-kata by Alain Martenot and Jose Maceda, ORSTOM - 1982 (page 7)

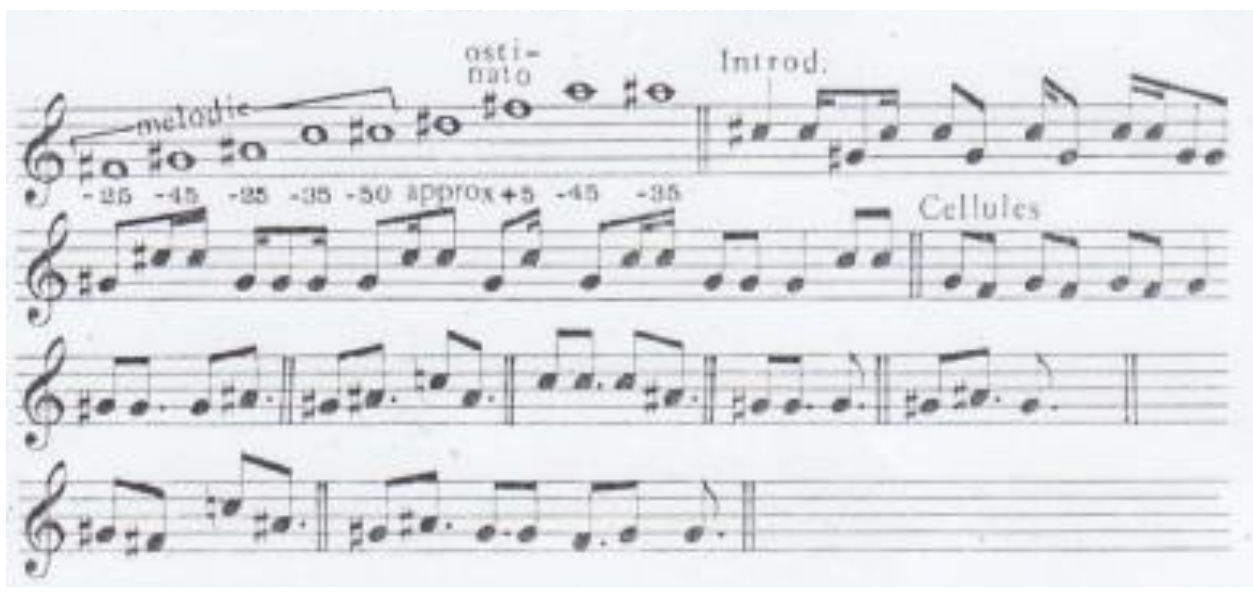

Figure 6: Titik Tabawan

Source: "Sama de Sitangkai," a record of music and excerpts of kata-kata by Alain Martenot and Jose Maceda, ORSTOM - 1982 (page 5) 


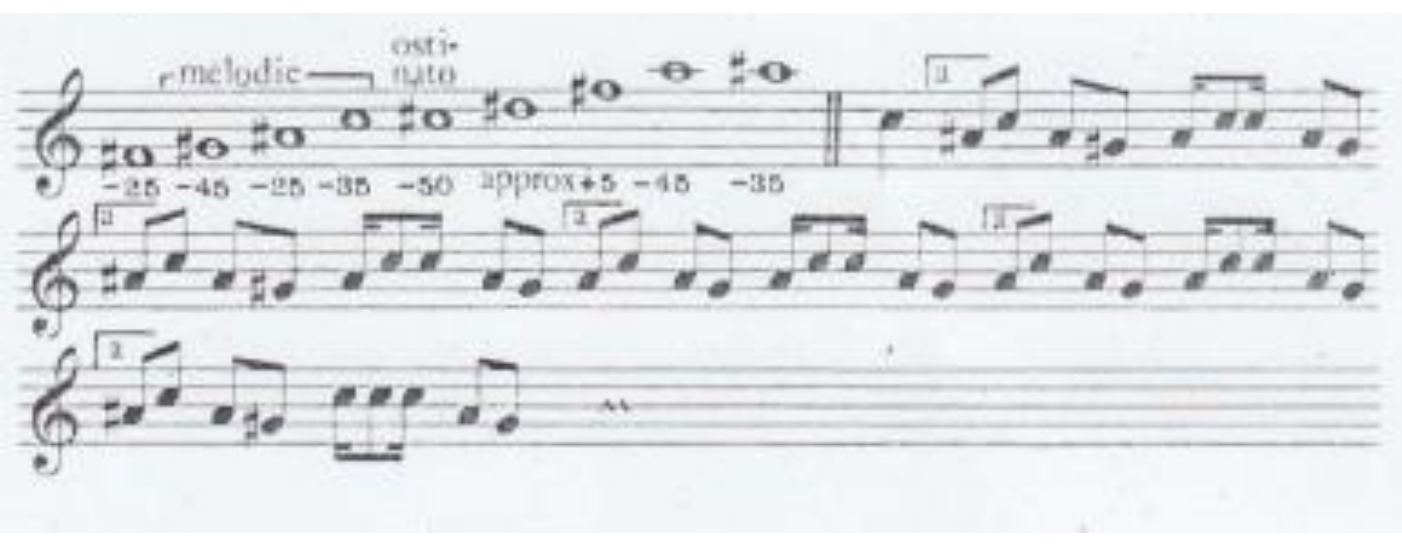

Figure 7: Titik Lellang

Source: "Sama de Sitangkai," a record of music and excerpts of kata-kata by Alain Martenot and Jose Maceda, ORSTOM - 1982 (page 7)

\section{Pagkanduli}

While ritual healing dance and music séancing of magduwata and magpa-igal may not be present in the Sama Dilaut communities in Sitangkai or the shallow reefs of TawiTawi of Southern Philippines, a similar form of gendering dance and music may be observed in their pagkanduli rituals. Pagkanduli means coming together to celebrate the bansa, spirits or ghosts, of benevolent ancestors associated with seas just as jins are celebrated and placated by the Bajau Kubang in Sabah. However, the bansa of Sama Dilaut are represented by male and female spirits such as Tuan Laut and Dayang Mangilai respectively. Being benevolent ancestors, contact between the spirit bearers and their spirit guides (bansa) is celebrated physically in the form of a ritual dance while spiritual contacts are reserved to the esoteric communicative competence between the spirit bearers and the spirit guides. A successful pagkanduli séance is achievable through full participation of conjugal families that are linked by kinship ties in a multifamily household, which may be part of household clusters forming a village. The kulintangan musical ensemble similar to the tagunggu' of the Bajau Kubang is played throughout the pagkanduli ritual but begins with the signalling of the igal dance by the senior-most spirit bearer. The dancing commences with igal limbayan exclusively performed by the female spirit bearers (igal jin denda) hierarchically from the seniormost female shaman to the youngest in tow. Ornamental extended faux fingernails or sulakengkeng and hand-held clappers or bola-bola are often used as properties associated with particular bansa (Hussin \& Santamaria, 2008) signifying their attendance in the ritual dance performance.

The hierarchical structure of pagkanduli dance and music repertoires continues when the leading séance shaman acknowledges the acceptance of the spirit guide or bansa and invites others to join in the dance. When the bansa becomes satisfied and agrees to release the spirit bearer from being under its spell, the last dance is performed by male spirit bearers (igal jin lella) in the form of igal lellang. The two igal dances, 
igal limbayan and igal lellang, are not only performed by specific gender groups but display contrastive stylistic differences, the former languid with curvaceous arms and hands movements extended from upright torso on pliant feet, the latter in the form of martial arts movements mirroring the kuntao of the Sama DiLaut and the Tausug.

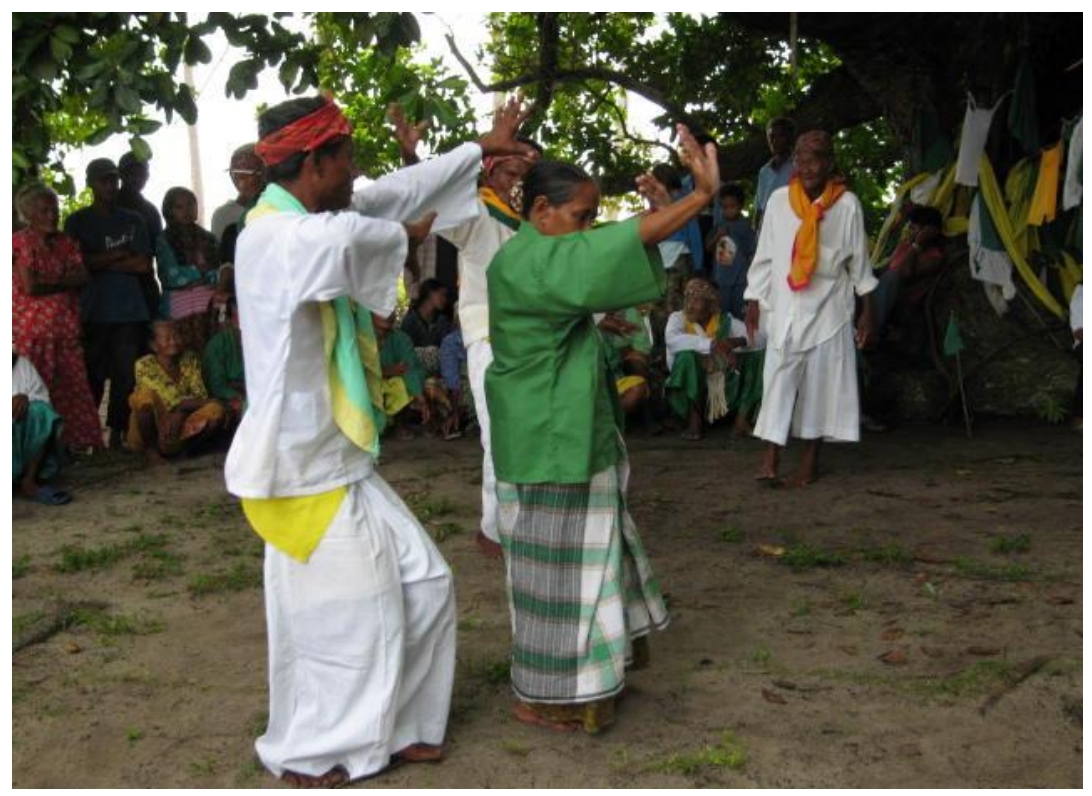

Figure 8: Igal by Jin Lella and Jin Denda in Pagkanduli Ritual of Sama Dilaut, Sitangkai Island, Southern Philippines (Source: Fieldwork, 2008)

\section{Gendering music}

Dancing (mag-igal) cannot happen without magtagunggu' or music-making. Hence, the ritual musical repertoire of magtagunggu' includes musical pieces (titik) and dances (igal) which is normally performed for non-ritual performance as well as specific ritual pieces and dance styles. The musical tunes of titik limbayan, titik lellang and titik tabawan (for Bajau Laut of Kampung Bangau-Bangau, it always refer to Titik LubakLubak, which used in the magpa-igal ritual) are performed with corresponding dancing styles known as igal limbayan, igal lellang and igal tabawan. These are performed by family members and guests spontaneously to celebrate the ritual occasion (Md Nor \& Hussin, 2006) as observed in magpai-bahau/magduwata ritual of Bajau Kubang in Kampung Kabimbangan, Semporna, Sabah.

Only titik limbayan and titik lellang, which are accompanied by the dances of igal limbayan and igal lellang, are music tunes designated for the jin or spirit mediums. These two music tunes are classified as tunes for the ancestors also called as titik duwata. Other than these tunes, which are accompanied by dance, there are additional tunes that are played to invite ancestral spirits to the realm of the living. These are titik tagna (introductory piece), titik jampi or titik jaupi (incantations for the ancestors), and titik lakkas-lakkas (is similar to titik tabawan from Tabawan island and titik lubaklubak-means to play fast and fast-played amongst the Tausug). 
In the magpa-igal and pagkanduli rituals of Sama Dilaut in Sitangkai of Southern Philippines and Bangau-Bangau of Semporna, Sabah, Malaysia, only three tunes (titik) are identified. These are the titik limbayan for jin denda (female spirit bearer), titik jin and titik lellang for jin lella (male spirit bearer).

Similar tagunggu'/kulintang tunes are played in the magpa-igal dance of the Bajau Laut in Bangau-Bangau village in Semporna, Sabah, as well as in the Southern Philippines' island of Sitangkai. However, unlike in the magpai-bahau and magduwata rituals of the Bajau Kubang, the tune of titik jin is only played for male spirit bearer (jin lella). Nevertheless, it is common in the rituals of magpa-igal and pagkanduli that titik limbayan is played by the tagunggu'/kulintang ensemble in the beginning repertoire of female spirit bearers (jin denda) who perform the igal limbayan dance. This is followed by titik jin for the dance of igal jin lella by the male spirit bearers, which is followed with the tunes of titik tabawan and titik lubak-lubak for female spirit bearers who dance the igal lellang. Hence, tunes of the tagunggu'/kulintang may correspond to gender specific dance of the spirit bearers when names of the musical tunes may also lend its name to the dance being performed. It has been observed that the male tune of titik lellang designated for male dancers and spirit bearers is marked by thunderous beating of the drum and gongs to facilitate and induce trance dancing during the ritual séance. Once in a trance, the spirit bearers (jin) danced vigorously, always stamping their feet on the wooden floor of the pile house, which reverberates the energetic movements of the male spirit guides in the body of the male spirit bearers (Baptist \& Regis, 2010).

Table 1: Tunes (titik) in the rituals of Magduwata, Magpaigal and Pagkanduli

\begin{tabular}{|c|c|c|c|}
\hline & Magduwata & Magpaigal & Pagkanduli \\
\hline 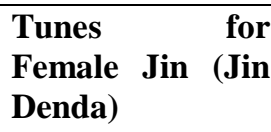 & Titik limbayan & Titik limbayan & Titik limbayan \\
\hline \multirow[t]{2}{*}{$\begin{array}{l}\text { Tunes for Male } \\
\text { Jin (Jin Lella) }\end{array}$} & & Titik Jin & Titik Jin \\
\hline & $\begin{array}{l}\text { Titik Lellang } \\
\text { As a final piece, titik } \\
\text { tabawan is played to the } \\
\text { accompanying of igal } \\
\text { tabawan. } \\
\text { Both are often referred } \\
\text { to as as titik duwata by } \\
\text { the community. } \\
\text { Other titik - titik } \\
\text { tabawan, titik jampi or } \\
\text { titik jaupi, titik lakkas- } \\
\text { lakkas is similar to titik } \\
\text { tabawan from Tabawan } \\
\text { island and titik lubak- } \\
\text { lubak }\end{array}$ & $\begin{array}{l}\text { Titik Lellang } \\
\text { Titik lubak-lubak marks } \\
\text { the end of magpa-igal and } \\
\text { is played for the leader of } \\
\text { the male spirit bearer. } \\
\text { Titik limbayan, titik } \\
\text { lellang and titik tabawan } \\
\text { are played as final pieces. }\end{array}$ & Titik Lellang \\
\hline
\end{tabular}




\section{Gendering dance}

Table 2: Dance (Igal) repertoire in the rituals of Magduwata, Magpaigal and Pagkanduli

\begin{tabular}{|c|c|c|c|}
\hline & Magduwata & Magpaigal & Pagkanduli \\
\hline $\begin{array}{l}\text { Dance for Female } \\
\text { Jin (Jin Denda) }\end{array}$ & Igal Limbayan & Igal Limbayan & Igal Limbayan \\
\hline \multirow[t]{3}{*}{$\begin{array}{l}\text { Dance for Male Jin } \\
\text { (Jin Lella) }\end{array}$} & Igal Jin & Igal Jin & Igal Jin \\
\hline & $\begin{array}{l}\text { Igal Tabawan }- \text { a finale } \\
\text { dance piece of the } \\
\text { magduwata ritual } \\
\text { accompanied by titik } \\
\text { tabawan. }\end{array}$ & Igal Lellang & Igal Lellang \\
\hline & $\begin{array}{l}\text { Titik Tabawan- played } \\
\text { for everyone to dance, } \\
\text { which includes all the } \\
\text { spirit bearers, i.e. Jin } \\
\text { Lella and Jin Denda as } \\
\text { well as participants and } \\
\text { observers of the } \\
\text { magduwata ritual } \\
\text { outsiders at the end of } \\
\text { the ritual event. }\end{array}$ & $\begin{array}{l}\text { Titik Tabawan- played } \\
\text { in the middle of the } \\
\text { ritual, enabling Jin } \\
\text { Denda and Jin Lella to } \\
\text { dance together at the } \\
\text { same time. }\end{array}$ & $\begin{array}{l}\text { Titik Tabawan- } \\
\text { played in the } \\
\text { middle of the } \\
\text { ritual, enabling } \\
\text { Jin Denda and Jin } \\
\text { Lella to dance } \\
\text { together at the } \\
\text { same time. }\end{array}$ \\
\hline
\end{tabular}

Mag-igal or dancing by participants and observers of the magduwata ritual and the playing of the tagunggu'/kulintang pot-gong ensemble (magtagunggu') are integral parts, which are virtuous and profound to the magduwata ritual. It is the culmination of celebratory moments in the intense rites of the prescribed ritual, cathartic and salutary, the former to ill health, while the latter to the spirits of the ancestors. Hence, individuals with the strongest inclination to fall into a trance while dancing are encouraged to take the role of dancing spirit bearer (igal-jin). For the rest who dance along threads liminal spaces as conduits for the merging of spirits of the ancestors and the living lineage. Jin, like humans, is gender-specific. Thus, possession by male or female jin is acknowledged through the playing of specific tunes (titik) (Md Nor \& Hussin, 2006). Titik Lellang is associated with male jin while Titik limbayan is recognized as possession by female jin. A spirit medium who dance the igal-jin (dance of the spirit bearer) hold a handkerchief in his right hand and areca palm fronds in his left hand. In a Malay myth, palm fronds from the areca plant has long been considered to be fodder for roaming spirits. The same may hold true with the Bajau Kubang.

In a specific case study on the magduwata ritual in the Onnong family in Semporna, the younger brother of Haji Bakhara bin Onnong, Haji Jenari bin Onnong, displays tendencies of an emerging jin (spirit bearer) as he dances with costumes from the ancestral heirloom. He is believed to be the bearer of ancestral spirits and the 
receiver of katurunan (ancestral lineage). As the jin falls into a trance, a member of the family would place a jimpau (handkerchief) on his or her shoulder to ensure that the dancing (mag-igal) becomes a trance dance of the spirit bearer (igal-jin). It is during the igal-jin that ritual healing takes place. The jin in trance takes the position of the healer by rubbing or massaging the sections of the anatomy of the sick person. The handkerchief (jimpau) is also used to beat the patient as trance dancing intensifies to a rapid pace. When dancing becomes arduous, the spirit bearer collapses onto the floor in a faint. He is soon revived by the shaman, who could also be the village Imam, to recover from his exhaustion.

In spite of the seemingly clear division of labor between dancing the mag-igal and dancing the spirit bearer (igal-jin), the perceived boundaries are often crossed over if someone who dances the mag-igal has the callings to become spirit mediums for their ancestral spirits. They too may perform trance-dancing and becomes the jin (spirit bearer) (Md Nor \& Hussin, 2006). At the end of the trance-dancing (igal-jin) and ritual healing, all members of the family continue to dance the mag-igal for the rest of the afternoon as they await the sun to set. At this juncture, the dance becomes spontaneous social-dancing which is often performed in a linear formation around the living quarters that was once a sacred healing space. When magduwata is about to end, a series of Islamic verses (an-Nas, al-Ikhlas, al-Falah, al-Fatihah, al-Baqarah) and a recitation of a doa (prayer) is performed to conclude the event, thus marking the end of a syncretic event of indigenous and Islamic rituals.

Contrastively, igal dancing in the magpa-igal ritual is performed both by the male spirit bearer (jin lella) and female spirit bearer (jin denda). The dance of the female spirit bearer (igal jin denda) is accompanied with the tune of titik limbayan while the dance is referred to as igal limbayan. In this slow and languid dance, body cologne is sprinkled onto the female spirit bearer as an inducement to bring forth spirit guides into the body of the dancing shaman. A burst of rapid and virtuosic movements of the body and hands marks the union of spirit guides into the body of the spirit bearer. Similarly processes are also observed in the dancing of the igal jin lella (dance of the male spirit bearer) when titik jin (for Bajau Laut/Sama DiLaut of Sitangkai) or titik lellang (Bajau Laut in Bangau-Bangau, Semporna, Sabah) are played during magpaigal ritual dance.

The same situation could be observed in the dance of the Pagkanduli ritual. As the igal jin denda dance, it is said that the female bansa (spirit guide) watches the performance being offered to them. If the music is particularly good especially during the portions with fast tempo, the bansa supposedly comes and dances together with the human performers. It is also said that they sometimes show their pleasure by entering the igal jin denda's body through a central spot of the head referred to as the imbun-imbunan (Hussin \& Santamaria, 2008). They therefore take temporary 
residence in the body of the igal jin denda. When they are in residence, the igal jin feels weary and oftentimes some pain. To release the bansa from their bodies, the igal jin should recite sacred words or phrases (kata-kata). This recitation may come in the form of chanting or incantation (Hussin \& Santamaria, 2008).

\section{Epilogues: Gazing music - Gendering dance}

Discussions on the tagunggu'/kulintang and igal for ritual healing (magpaibahaumagduawta) or celebrating of progenitors' spirits (pagkanduli) so far have shown that music of tangunggu'/kulintangan ensemble tells of events beyond conventional soundscapes. Music not only accompanies dance and ritual activities but facilitates the crossing of worlds between the living and the spirit guides (jin or bansa) through the interactive actions of the spirit bearers (jin or limbayan) during séance dancing (igal jin/igal limbayan). In other words, the tunes of tangunggu'/kulintang are not only meant to identify the genders of spirit bearers at pre- and post-séance dancing but are signifiers of gendered spirit guides that have entered (masuk) the bodily abode of the spirit bearers. Some generic examples of tunes (titik) associated with specific genders of dancing spirit bearers highlighted by this paper are as follows; titik limbayan for dancing female spirit bearers (igal limbayan), titik tabawan for dancing male and female spirit bearers (igal jin and igal limbayan) or for communal dancing (magigal), and titik jin or titik lellang for dancing male spirit bearers (igal jin). All of the titiks and igals in séance dancing (magpa-igal) in magduwata and pagkanduli follow an archetypical generic sequencing as mentioned above.

In this context, the type of tunes chosen for the spirit guides during séance dancing is determined by several factors. First, tunes chosen to induce trance for the spirit bearers are determined by the biological sex of the spirit bearers (jin or limbayan). Secondly, tunes are changed to satiate the continual presence of the spirit guides that have entered the bodily realm of the spirit bearers irrespective of the biological sex of the spirit bearers when séance dancing (magpa-igal) begins and it will last as long as the séance continues. Thirdly, tunes would again change when spirit guides have left the performative space signified by visible exhausted spirit bearers, falling to the floor in spasms of convulsive fits. At this point, dancing (magigal) becomes a communal event to celebrate successful completion of séance dancing cycle. Musicians are either informed by the senior male spirit bearer (jin) to play different tunes at the point when spirit guides are known to have entered (masuk) the bodily space of the junior spirit bearers or by their head or senior musician who may have acquired communicative competence in recognising the presence of the spirit guides.

While the intrinsic knowledge of gazing the spiritual presence of spirit guides during séance dancing during magpaibahau-magduwata and pagkanduli remains as esoteric skills of the Bajau Kubang and Sama Dilaut, academic speculation may suggest 
that indigenous musicians and observers alike may have learnt subtle kinaesthetic nuances of séance dancing in the way as parole is to communicative competence. At the broad level of competence, igal dance is performed with stylistic gender differences. Female dancers are generally more fluid with their hands, extending, curling and flexing their fingers with or without the faux fingernails (sulingkengkeng or janggay) to accentuate and amplify arms and hands movement while sustaining relatively upright torso. The male dancers, on the other hand, are agile and display martial art-like movements of kuntao or langka (Md Nor, 2003). But within and between these broad dance motifs, are the smallest meaningful units of dance movements (morphokines) that are idiosyncratically different from the conventional movements, performed or practiced knowingly by members of their communities. These are probably interstices or empty spaces between spaces full of structured movements that are filled with dynamics of body movements and gestures peculiar to performance styles of gendered spirit guides. It is perhaps within these interstitial spaces that the music gazes the mastering of the esoteric knowledge in capturing the gendered dance movements.

\section{Acknowledgement}

This Paper Is An Output Of Research Funded By RP017D-13SBS (Ethnographic Study Of Shared Traditional Food Heritage Of Coastal Communities Of The South China Sea, RG155-12SUS (Mapping the Bajau: Origins, Performance and Cultural Sustanaibility of the Bajau Community in Sabah, Malaysia and Sulawesi, Indonesia) and RU009F2018 (Local Knowledge, Heritage And Development Among Coastal Community of Malaysia: Case Of Study of Semporna, Sabah).

\section{References}

Baptist, J. J., \& Regis, P. (2010). Magpa-igal Jin: A ritual dance, linking the past with the present among the Sama Dilaut of Sabah. Paper presented at International Conference, Oceans of Sound: Sama Dilaut Performing Arts Conference, Amsterdam, Netherlands, $9^{\text {th }}$ September 2010.

Bottignolo, B. (1996). Celebrations with the sun: An overview of religious phenomena among the Badjaos. Quezon City: Ateneo de Manila Press.

Fernando, S. (2002). Tagunggu practice by the Bajau of Semporna, Sabah. Tirai Panggung, 5, 17-29.

Hussin, H. (2004). Field Notes September 17-19, 2004. Research on Magduwata in Kampung Kabimbangan Tengah, Bum Bum Island, Semporna, Sabah. 
Hussin, H. (2005). Field Notes January 8-9, 2005. Research on Magduwata in Kampung Kabimbangan Tengah, Bumbum Island, Semporna, Sabah.

Hussin, H. (2009). Diaspora Bajau Laut dan pengekalan serta penerusan amalan tradisi di Sabah (Bajau Laut's Diaspora and preservation of their traditional practices in Sabah). Borneo Research Journal, 2,149-163.

Hussin, H., \& Santamaria, MCM. (2008). Dancing with the ghost: Experiencing the Pagkanduli ritual of Sama Dilaut (Bajau Laut) in Sikulan, TawiTawi, Southern, Philippines. JATI (Journal of Southeast Asian Studies), 13, 159-172.

King, V. T. (1993). The peoples of Borneo. Oxford: Blackwell Publishers.

Md Nor, M. A., \& Hussin, H. (2006, July 10-17). Mag-igal and Igal-Jin: Dancing the spirits of the ancestors in the rituals of Magduwata of the Bajau Kubang in Bumbum Island, Semporna, East Malaysia. Paper presented at 24th Ethnochoreology International Symposium, Cluj, Romania.

Md Nor, M. A., \& Hussin, H. (2007, April 7). Mag-igal and Igal-Jin of Bajau Kubang: Invoking liminality for the spirits of the ancestors in Semporna, Sabah. Paper presented at the Conference on Shamans and Spirit Mediums, Asian Civilization Museum Singapore, Singapore.

Md. Nor, M.A. (2003). Arabesques and curvilinear perimeters in the aesthetics of maritime-Malay dances. 2003 Yearbook for Traditional Music, International Council for Traditional Music, 35, 179-181.

Md. Nor, M.A. (2005). Field Notes January 8-9, 2005. Research on Magduwata in Kampung Kabimbangan Tengah, Bumbum Island, Semporna, Sabah.

Pugh Kitingan, J., Hussin, H., \& Baptist, J.J (2005). Dance as ritual, dance as celebration- Tradition and change amongst the Bajau of Semporna, Sabah, Malaysia. In M.A. Md Nor \& R. Murugappan, Global and Local Dance in Performance (207-219). Kuala Lumpur: Cultural Centre, University of Malaya \& Ministry of Culture, Arts and Heritage Malaysia.

Sather, C. (1997). The Bajau Laut: Adaptation, history, and fate in a maritime fishing society of South-Eastern Sabah. New York; Kuala Lumpur; Singapore: Oxford University Press.

Sather, C. (2000). Bajau Laut boat building in Semporna. Techniques \& Culture, 35-36, 177-198.

Sather, C. (2004). Keeping the peace in an island world of violence: Sama Dilaut ways of managing conflict. In A. R. Walker, Leadership, justice and politics at the grassroots (pp. 127-158). Contributions to Southeast Asian Ethnoghraphy, No.12: 131.

Walton, J. R., \& Moody, D. C.(1984). The East Coast Bajau Languages. In J.K. King \& J. W. King, Languages of Sabah. A Survey Report (pp. 114- 
119). Pacific Linguistics Series C, No. 78. Canberra: Australian National University, 1984 reprtd.1997

\section{Interview}

Intan Sulga, Kampung Bangau-Bangau, Semporna, Sabah, April 2005

Haji Bakhara, Semporna, Sabah, April 2004.

Communication with MCM Santamaria, who performed fieldwork in Sitangkai, Southern Philippines in 2008.

Date Received: 15 September 2018 Date of acceptance: 15 June 2019 